\title{
Deleterious FANCF Gene Mutation
}

National Cancer Institute

\section{Source}

National Cancer Institute. Deleterious FANCF Gene Mutation. NCI Thesaurus. Code

C150153.

A change in the nucleotide sequence of the FANCF gene that is associated with increased risk of disease. 